\title{
Exergoeconomic analysis of the Allam cycle
}

Supporting information. Selected thermodynamic properties, exergy and exergoeconomic values of the material streams of the plant.

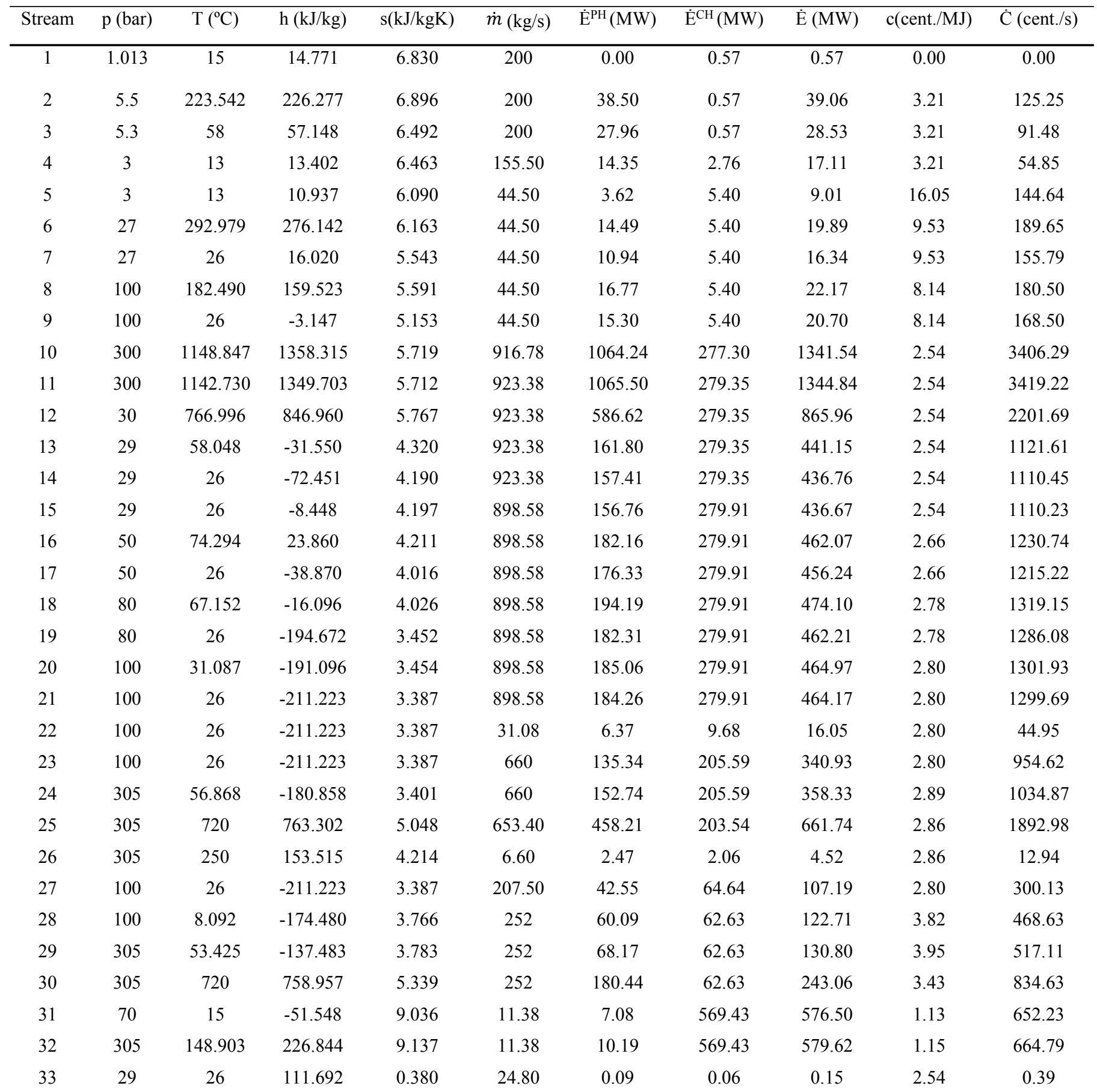




\begin{tabular}{|c|c|c|c|c|c|c|c|c|c|c|}
\hline 34 & 1.013 & 15 & 63.079 & 0.224 & 1503.62 & 0.00 & 3.76 & 3.76 & 0.00 & 0.00 \\
\hline 35 & 1.013 & 21 & 88.197 & 0.311 & 1503.62 & 0.39 & 3.76 & 4.14 & 3.25 & 13.46 \\
\hline 36 & 1.013 & 15 & 63.079 & 0.224 & 2244.07 & 0.00 & 5.61 & 5.61 & 0.00 & 0.00 \\
\hline 37 & 1.013 & 21 & 88.198 & 0.311 & 2244.07 & 0.58 & 5.61 & 6.18 & 3.02 & 18.67 \\
\hline 38 & 1.013 & 15 & 63.079 & 0.224 & 6388.26 & 0.00 & 15.96 & 15.96 & 0.00 & 0.00 \\
\hline 39 & 1.013 & 21 & 88.198 & 0.311 & 6388.26 & 1.65 & 15.96 & 17.60 & 2.43 & 42.86 \\
\hline 40 & 1.013 & 15 & 63.079 & 0.224 & 720.02 & 0.00 & 1.80 & 1.80 & 0.00 & 0.00 \\
\hline 41 & 1.013 & 21 & 88.197 & 0.311 & 720.02 & 0.19 & 1.80 & 1.98 & 2.42 & 4.81 \\
\hline 42 & 1.013 & 15 & 63.079 & 0.224 & 460.83 & 0.00 & 1.15 & 1.15 & 0.00 & 0.00 \\
\hline 43 & 1.013 & 21 & 88.198 & 0.311 & 460.83 & 0.12 & 1.15 & 1.27 & 27.24 & 34.59 \\
\hline 44 & 1.013 & 15 & 63.079 & 0.224 & 288.19 & 0.00 & 0.72 & 0.72 & 2.89 & 1034.87 \\
\hline 45 & 1.013 & 21 & 88.198 & 0.311 & 288.19 & 0.07 & 0.72 & 0.79 & 2.86 & 1892.98 \\
\hline
\end{tabular}

